\title{
Development laws and controlling factors of karst in Longyan, Fujian province, China
}

\author{
Yongxiang $\mathrm{Chi}^{1, \mathrm{a}}$ \\ ${ }^{1}$ Fujian Institute of Geological Survey, Fuzhou, Fujian, 350011, China \\ acyx000sky@126.com
}

Keywords: Longyan; karst; development law; controlling factor

\begin{abstract}
Longyan is a main region developing karst in Fujian province, China. Based on the extensive studies, this study systematically investigated the development law and controlling factors of the karst in Longyan. The results indicated that the development of karst in this region is mainly controlled by the lithological association of soluble rocks, and geological tectonics serves as the main controlling factor, while the effect of the groundwater in karst area constitutes the dynamic condition. Meanwhile, karst is also influenced by various factors including topography. The combined effects mainly led to the uneven distribution and development of karst in this region.
\end{abstract}

\section{Introduction}

Longyan is a region which severely suffered karst surface collapse in Fujian, China. In addition, the groundwater in karst area is one of the most important water resources for urban water supply. Therefore, karst collapse has significantly affected the industrial and agricultural production, transportation safety and human settlements in recent years. At present, the studies on the development of karst concerning this region are mainly focused on the hydrogeological aspects and relevant geological surveys, while fail to systematically research the development characteristics of karst in this region. Through surface survey, this study systematically analyzed the development laws and influencing factors of karst in Xinluo district on the basis of a large amount of exploration data and regional geology. Therefore, it is of great guiding significance to construction planning, construction engineering and prevention of karst collapse in Longyan ${ }^{[1]}$.

\section{Geological backgrounds}

Various strata are developed and mainly distributed in the east and south of this region. They are mainly composed of sedimentary rocks in Devonian system, Carboniferous system, Permian system and Triassic system, along with metamorphic rocks in Silurian-Ordovician system and red-bed formation in Cretaceous system. In addition, few volcanic rocks in Jurassic system are outcropped in the southeast of this region. Subject to the tectonics in Cathaysia and Neocathaysian systems, the outcropped rocks are primarily distributed in NE-strike and then extend in a belt form. Soluble rocks, although sparsely distributed, they are NE-SW oriented on the whole. They are mainly found in the strata of Carboniferous system, Permian system and Triassic system and composed of Jingshe $\left(\mathrm{C}_{2} j\right)$, Chuanshan $\left(\mathrm{P}_{1} c\right)$, Qixia $\left(\mathrm{P}_{2} q\right)$ and Xikou $\left(\mathrm{T}_{1} x\right)$ formations. The development and distribution of Quaternary system which is NNE- and NW- oriented are mainly controlled by Neocathaysian system and the new tectonic line. It is distributed on both sides of river valleys in intermountain basins, such as, Longyan, Shizhong, Yanshi, etc., and foots of mountains. Holocene sediments widely distributed, followed by other strata with significant change in thickness ${ }^{[2]}$.

This region, belonging to the tectonic unit in southwestern Fujian, is located in the northwest of the Zhenghe-Dapu deep fracture. It has experienced several times of tectonic movements in long geological history, thus forming diverse tectonics, such as, folds, fractures and magmation. Due to such complex tectonics, the strata are fragmented. From the east to the west, there are mainly horizontal compressive tectonic belts, while SN directed slip fault zones represented by folds and tense-shearing ones, and NE-SW-trended compressive and compresso-shearing fault tectonics. 


\section{Development law of karst}

The development of karst is affected by diverse factors including tectonics, lithology and topography. Although the development law is complex, they still present certain law on the whole ${ }^{[3]}$.

\subsection{Planar zonation}

In terms of planar distribution, karst gradually enhanced from the mountainous areas surrounding the basins to the plains in the center of the basins. Both sides of the rivers in the center of the basins are mainly the draining areas of karst water with intense hydraulic action being found. Karst caves are developed densely in a large scale in river plains where thus become the main development areas of karst. The mountainous areas around the basins, supplying for karst water, develop little karst, thus are the areas for weak karst. Piedmont hills and tablelands between these areas are the runoff areas of karst water. Here, karst moderately develops.

Table1 Characteristics of karst development in the plane

\begin{tabular}{|l|l|l|l|}
\hline geomorphic unit & lower mountain & hill platform & valley plain \\
\hline $\begin{array}{l}\text { A high of karst cave In single } \\
\text { bore }(\mathrm{m})\end{array}$ & Cave in individual & $1 \sim 3$ & $>5$ \\
\hline water abundance & poorness & middle & rich \\
\hline
\end{tabular}

\subsection{Vertical stratification}

In the shallow areas of this region, groundwater comes from various sources, which show good permeability and strong dissolution. Therefore, it is favorable to develop karst here. However, with the increasing depth, the recharge sources become farther, permeability and dissolution were weakened. Therefore, the development of underground karst caves in the Longyan basin is characterized by reducing number, and weakened permeability and dissolution until disappearance from shallow areas to deep areas. These caves are mainly developed within $50 \mathrm{~m}$ under the ground, especially favorably developed within $20 \mathrm{~m}$. This obviously proves the development characteristic of karst ${ }^{[4]-}$ the increasing depth leads to the reduced properties.

Table2 Characteristics of karst development in the vertical profile

\begin{tabular}{|c|c|c|c|c|c|}
\hline depth $(\mathrm{m})$ & $0 \sim 10$ & $0 \sim 10$ & $20 \sim 30$ & $30 \sim 40$ & $40 \sim 50$ \\
\hline The number of cave & 15 & 93 & 50 & 24 & 4 \\
\hline The thickness of karst (m) & 39.7 & 433.02 & 397.63 & 178.8 & 40 \\
\hline Total height of cave (m) & 15.7 & 179.52 & 104.67 & 42.4 & 4.3 \\
\hline karst rate (\%) & 39.55 & 55.26 & 41.42 & 34.90 & 35.75 \\
\hline Fully & 11 & 87 & 44 & 15 & 1 \\
\hline Partly & 1 & 4 & 0 & 4 & 1 \\
\hline cavity & 3 & 2 & 6 & 5 & 2 \\
\hline Filling caly & 15 & 91 & 41 & 24 & 4 \\
\hline Filling Cohesionless Soil & 2 & 3 & 4 & 0 & 0 \\
\hline Filling gravel-cobble & 0 & 1 & 1 & 0 & 0 \\
\hline
\end{tabular}

\subsection{Filling of karst caves}

\subsubsection{Filling degree of karst caves}

(1) The karst caves in shallow areas are largely filled, while those in deep part are little filled. The filling degree of karst caves weakens with the increase of the depth. This is because the karst caves in shallow areas are close to the material sources, while the deep caves are farther from the material sources. In addition, the permeability and dissolution of groundwater show the same Law.

(2) High karst caves show a high filling rate, while low caves presents a low filling rate. The higher the karst caves, the greater the filling rate is. This is because for the large scale karst caves, the river cross- section of groundwater is large with small flow rate. Consequently, the materials carried in the groundwater can easily be precipitated. In contrast, for small karst caves, the rive cross-section is small with large flow rate, the materials are unlikely to be deposited, thus having small amount of filling materials. 


\subsubsection{Properties and distribution of filling materials in karst caves}

In this region, the filling materials in karst caves are mainly external substances, along with few dissolved residues. There are many kinds of filling materials, such as clay, pebble and boulder. In general, these materials are difficult to be separated as clay is mixed with pebble, or gravel or sand clay is mixed with crushed gravel. While a part of the materials can be easily chosen as they are alternatively distributed with horizontal beddings. In the valley plains (e.g. Dongxiao, Caoxi, Xibi and Tieshan) in the center of the basins, the filling materials in karst caves are mainly composed of coarse particulate matters including dust-containing stony clay and sandy gravel. While for piedmont of low mountains, piedmont hills and tablelands, and bare karst areas (Qingcaoyu, Jiufeiyan, Xinan and Lijiaping), the filling materials are mainly constituted by fine particulate matters including clay, sand clay, clay sand or crushed gravel mixed with soil. In addition, in local valley plains, for example, Hongfang district, sand clay mixed with crushed gravel and pebble gravel of slope-proluvium are found under alluvium-proluvium. Therefore, the karst caves in this region are mainly filled with these materials ${ }^{[5]}$.

To sum up, the filling materials of karst caves in this region are closely related to the properties of surrounding rocks. In general, the karst caves with a high filling rate show weak water abundance; otherwise, the water abundance is strong. The filling materials with coarse particulates are easily to be separated and present favorable water abundance, and vice versa. This is a general law found in this region.

\section{Factors controlling the development of karst}

The development of karst is comprehensively controlled and influenced by the strata association types of soluble rocks, rock structures, chemical components, tectonics, topography, groundwater, etc. On the whole, the distribution of karst in this region is mainly controlled by soluble rocks and water circulation. In addition, geologic tectonics, neotectonics and landforms can also exert a significant influence on the distribution of karst ${ }^{[5]}$.

4.1 The lithology of soluble rocks

Carbonate rocks, as a kind of soluble rocks, their corrosion and development mainly rely on the contents of calcium oxide and acid insoluble matters in rocks. This is the internal cause for the development of karst.

4.1.1 Strata association types of limestone

Karst is mainly distributed in thick soluble rock strata and concentrated on the chert limestone strata of $\mathrm{P}_{2} q^{[6]}$. It has been revealed that karst caves in the basins are situated in chert limestone strata of $\mathrm{P}_{2} q$ of Permian system. Thick karst is intensely corroded; while the development of thin karst containing many impurities is relatively weak. As the content of $\mathrm{CaO}$ in the pure limestone strata of $\mathrm{C}_{2} j-\mathrm{P}_{1} c$ and the chert limestone strata of $\mathrm{P}_{2} q$ exceeds $50 \%$, karst develops intensely and therefore karst caves here are intensive in a large scale. Most of the known karst caves are developed in these two strata. However, as the pure limestone strata of $\mathrm{C}_{2} j-\mathrm{P}_{1} c$ cover a small area and are distributed sporadically, this region is mainly situated with the chert limestone strata of $\mathrm{P}_{2} q$. For the $\mathrm{P}_{2} q^{\mathrm{S}}$ strata mainly composed of siliceous rocks, karst caves are neither found on the ground or in boreholes. Limestones are distributed unevenly in the Lantian of Xikou formation $\left(\mathrm{T}_{1} x^{l}\right)$, which are primarily discovered in strata with moderate thickness and extreme thickness. However, they present a high content of Cao and therefore karst develops well here. In addition, hornstones, limestones and mudstones are mixed in some strata, where the development of karst is weak.

\subsubsection{Chemical factors for lithology}

Pure limestones present a high content of $\mathrm{CaO}$ and few impurities and therefore can easily be corroded under the effect of groundwater. After this process, they are taken way and form various forms of karst. Therefore, karst develops intensely with a high rate of karstification in such strata. In contrast, little $\mathrm{CaO}$ but many impurities are discovered in impure limestones and therefore they are difficult to be dissolved, especially for siliceous limestone and marlstone. As a consequence, karst develops weakly. 


\subsubsection{The structure of rocks}

The structure of rocks is closely related to their dissolution. Different structures and structural types influence the relative speed of rocks dissolved. In addition, many primary pores are found in carbonate rocks, such as, the pores among particles, or biologic skeletons, biogenic body cavities and crystalline grains. The porosity of these pores generally varies from 0.2 to $34 \%$ and is closely related to the corrosion velocity and development of karst. On the one hand, the pores in rocks provide channels for waters; on the other hand, they increase the contact area between rocks and water, thus accelerating the dissolution ${ }^{[7]}$.

In this region, the strata in $\mathrm{P}_{1} c$ and $\mathrm{P}_{2} q$ are generally thick with massive crystallites, micrites and limestone powder. Contain a large amount of biodetritus, a majority of these rocks are in micrite or crystallites structures with primary pores developed. Therefore, the rocks can be easily dissolved, thus helping to the development of karst. The smaller the particles in crystalline carbonate rocks, the larger the solubility of the rocks with relatively developed beddings is.

In contrast, the interlayers of limestone and mudstones in the Liantan strata of Xikou formation are found with complex components, among which the content if impurities exceeds $30 \%$. Therefore, the solubility of karst is poor, and karst is relatively undeveloped. While parts of the strata are composed of micrites and fine grains, thus karst developing here.

\subsection{Geologic tectonics}

\subsubsection{The control of fold structures over karst}

The strong and weak karst zones in this region accord well with the main tectonic line. The axes of anticlinorium in the basins together with a series of NNE-trended fractures control the distribution of strong karst zones: medium karst areas develop in the axes of anticlinorium, while the axes of synclinorium in the two swings of anticlinorium are found with weak karst areas. For example, in Tieshan district, karst develops favorably along the boreholes nearby anticlinal axes and tensional faults. Total 23 and 19 karst caves are discovered with the overall heights being $37.72 \mathrm{~m}$ and $45.39 \mathrm{~m}$, separately. For these caves, the rates of karstification are $21.8 \%$ and $14.7 \%$, respectively. In addition, for the boreholes along anticlines in Hongfang district, karst caves with the total heights of $26.10 \mathrm{~m}, 30.96 \mathrm{~m}, 11.71 \mathrm{~m}$ and $32.06 \mathrm{~m}$ are observed, separately. Besides, karst caves with the overall height being over $10 \mathrm{~m}$ are found in the boreholes along anticlines in Caoxi district $^{[8]}$.

All these indicate that anticlines formed under the effect of buckle folding are situated in the collapse position of the turn end of anticlines, thus providing space for the development of karst. In the area where the stress and deformation are tensile, a set of conjugate shear joints and longitudinal tension joints can be formed in the turn end. Longitudinal joints in the cross section of folds open downwards in wedge manners with wide fractures, rough fracture surface and poor cementing properties. Multiple sets of longitudinal joints develop along the hub, thus forming tensile fracture zones. These zones are not only conducive to the development of karst, but also help to the movement of groundwater. In this way, favorable is groundwater storage space formed in the fractured rocks in the anticlinal axes, thus helping to the occurrence of karst. The wings of anticlines and underground areas are mainly subjected to compression, so that fractures are gradually closed until they disappear. Under such condition, water in fractures is separated, and therefore is unfavorable for the development of karst. Therefore, the axes of anticlinorium in the center of Longyan district reflect the development law of karst. That is, the development intensity of karst reduces with the increase of the depth ${ }^{[9]}$.

\subsubsection{Control of fracture structures over karst}

Geologic tectonics, especially facture structure, is an important condition for the development of karst. To a large extent, the development of karst is controlled by the mechanical properties of fractures, cementing properties of tectonites, the development and scale of fractures and their combination relation with other tectonics. Therefore, they can significantly affect the development of karst. In this region, karst generally develops along fault zones which obviously control the development of karst ${ }^{[10]}$.

The limestone in the intersection part of tensional fractured fault zones, compressive or 
compresso-shearing fractures with fractures is damaged, where rocks are broken while fractures develop with the ratio reaching 7.2 13\%. After long term of dissolution, the fractures are extended continuously and karst caves and dissolved-fissures with different sizes develop along the fractured fault zones. Large bare karst caves in this region basically accord with the tectonic line in the longitudinal direction. For example, controlled by the EW-trended tectonics, the Longkong cave is found with EW-trended karst caves. karst develops intensely in the districts with fractures developed, especially in the distribution zones of tensile fractures nearby fractures and the tensile fracture zones in the axes of anticlines. In addition, the development of karst in the boreholes nearby both sides of faults is generally found intense, especially for the boreholes nearby extensional faults.

\subsection{Groundwater}

For the karst water in this region, it is mainly supplied by the atmospheric precipitation, bedrock fissure water and the vertical infiltration of pore water in overlying unconsolidated formation. The water flows downwards and drains along the karst channels. The water from these three sources is soft water with low mineralization degree and can continuously supply for the karst water. On the one hand, it can dilute the solutes in karst water and therefore reduces the saturability and maintains the dissolving capacity of water; on the other hand, this remains the fluidity of groundwater and ensures the dissolution ability of groundwater by taking away a part of solutes in water ${ }^{[11]}$.

\subsubsection{Dissolution ability of groundwater}

In this region, the limestone in $\mathrm{P}_{2} q$ generally contacts with the sandshale in the coal seams of the overlying Tongziyan formation, sandshale in Wenbishan and quartz sand-gravel in underlying Devonian in faults. The fault contact zones form surface valleys. In late Yanshanian, the limestone in $\mathrm{P}_{2} q$ was metamorphic owing to the granite intrusion. In terms of landform, the sandshale in the coal seams not only covers on the limestone in $\mathrm{P}_{2} q$, but also outcrops with a larger part than limestone blocks. Under such condition, the water out from coal measure strata is supposed to flow along the slopes or vertically into the limestone blocks. While the water from coal measure sand shows a $\mathrm{pH}$ value of 3.78 4.73 with the content of SO4 ${ }^{2-}$ reaching $240 \mathrm{mg} / \mathrm{l}$. The surface water from mudstone mixed with thin sand stone and granite regions and the water with $\mathrm{pH}$ value varying from 6.85 to 7.25 and a little content of $\mathrm{Ca}^{2+}$ and $\mathrm{HCO}_{3}{ }^{-}$can also flow into the limestone blocks. For the limestone blocks outcropped, they are expected to enter into the limestone again after rainwater infiltrates soil and dissolves the $\mathrm{CO}_{2}$ in soil. Therefore, a unique dissolution process by carbonated water and sulfuric acid water is formed in Longyan. This contains not only the karstification of single carbonated water or sulfuric acid, but also the synergistic karstification of these two kinds of acids, thus accelerating the corrosion velocity of soluble rocks ${ }^{[12]}$.

\subsubsection{The fluidity of groundwater}

The karst in this region is mostly located in the cores of synclines or karst valleys in negative relief, showing a good condition for ground water flow. Therefore, groundwater here flows quickly. In addition, this region presents humid climate and abundant participation, thus sufficiently supplying groundwater. With the infiltration of surface water into underground, groundwater is sufficiently supplemented and therefore the water is difficult to be statured. Or after being statured, it is quickly diluted so that it maintains high dissolution ability.

Similarly, the further development of karst provides wider dissolution channels and space for the circulation and alternation of groundwater and significantly enhances the fluidity of groundwater. As a consequence, groundwater has lasting dissolution ability, thereby influencing the further development and extension of karst.

\subsection{The topography}

Karstic basins, such as Longyan basin and Shizhong basin, are situated in tilting axes, presenting negative terrain and relatively slow slope. They therefore are conductive to gathering and infiltrating groundwater and surface water in a large area. In addition, as tectonic fractures develop, a large amount of precipitation is infiltrated into underground and therefore the alternation and circulation of groundwater become more frequent, thus helping to the development of karst. 


\section{Conclusions}

The factors controlling the development of karst in Longyan many include lithology, geologic tectonics, groundwater, topography, etc. Thereinto, the lithology, tectonics and groundwater effect are proven to be the base, main controlling factor and dynamic condition for the development of karst. Meanwhile, karst is also affected by multiple factors including topography. These factors can influence and restrict each other and are the primary cause for the uneven distribution and development of karst in this region. Although the geological conditions in this region are complex, the development of karst still generally shows certain law. Since the exploitation of groundwater in karst area in this region from the 1970s, environmental geological problems including karst collapse and fall of the water level have appeared. Therefore, studying the development characteristics and influencing factors of karst can provide a scientific basis for the development and protection of groundwater resource and project planning and construction.

\section{References}

[1] YX CHI,CH PAN,YH K,et al. The karst collapse investigation report inLongyan City, Fujian Province. Fujian Institute of Geological Survey, 2014.

[2] SZ GAO,SX ZHENG,LD CHEN,et al. The water supply hydrological investigation report inLongyan City, Fujian Province.The Hydrological Geology Team of Fujian geology and minerals bureau,1977.

[3] CM LIU,CS QIU,CZ WEN.The water supply regional investigation investigation report inLongyan City, Fujian Province. The eight Hydrological Geology Team in fujian, 1998.

[4] GX YI,F LI.The Developing Characteristics Of Karst Cave And Earth Cave In Covered Karst Area In Songgang Town,Nanhai District,Foshan City[J].GUANGDONG GEOLOGY,2003,18(3) ,p. 38-43.

[5]WZ ZHOU,YS WANG,GD CHEN,et al.Karst development and influence factors in Wushan Copper Mine,Jianxi Province.THE CHINESE JOURNAL OF GEOLOGICAL HAZARD AND CONTROL[J].2008,19(2) ,p. 124-127.

[6] Qinghua Li,Haitan Zhang, Yongze Huang,et al. Characteristics of Karst Development in Gele Mountain Area, Chongqing [J].Chinese Journal of Underground Space and Engineering. 2015,7 (11) , p. 347-351

[7] Xiaozhan ZHENG,Yu GUO,Jingling DAI,et al.Karst Development and Influencing Factors in Typical Karst Collapse [J].TROPICAL GEOGRAPHY.2014,34(6) ,p.794-803

[8] RONGIERA G,COLLON-DROUAILLETA P,FILIPPONIB M.Simulation of 3D karst conduits with an object-distance based method integrating geological knowledge [J]. Geomorphology, 2014, 217 , p.152- 164

[9] YX LIU,ZY DU. Study on Karst Development Features and Genetic Mechanism in Urban Area of Xuzhou[J]. JIANSU WATER RESOURDES,2014,10 ,p.30-32

[10] SONGAK,CHOB G C,CHANGC S B.Identification, remediation and analysis of karst sinkholes in the longest railroad tunmel in South Korea[J]. Engineering Geology, 2012, 135 /136 , p. 92- 105

[11]DURINGERA P,BACONB A M,SAYAVONGHAMDYC T, et al. Karst development, breccias history, and mammalian assemblages in Southeast Asia: A brief review [J].Geomorphology, 2014. 217 , p.152-164

[12] FIDELIBUSA M D,GUTIERREZB F,SPILOTROC G.Human-induced hydrogeological changes and sinkholes in the coastal gypsum karst of Lesina Marina area(Foggia Province, Italy) [J].Engineering Geology,2011,118(1/2),p.152-164

[13] COOPER A H,FARRANT A R,PRICE S J. The use of karst geomorphology for planning, hazard avoidance and development in Great Britain [J].Geomorphology,2011,134(1/2),p.118-131 